\title{
Innovative Thinking of Human Resources Management in Colleges and Universities
}

\author{
Weijie Su \\ City Institute, Dalian University of Technology, Dalian, China \\ Email: suweili2007@163.com
}

How to cite this paper: Su, W.J. (2021) Innovative Thinking of Human Resources Management in Colleges and Universities. Open Access Library Journal, 8: e7926. https://doi.org/10.4236/oalib.1107926

Received: September 3, 2021

Accepted: September 23, 2021

Published: September 26, 2021

Copyright $\odot 2021$ by author(s) and Open Access Library Inc.

This work is licensed under the Creative Commons Attribution International License (CC BY 4.0).

http://creativecommons.org/licenses/by/4.0/

\section{(c) (i) Open Access}

\begin{abstract}
The implementation of human resource management in universities is determined by the special nature and strategic position of universities. Good human resource management can improve the level of competition in colleges and universities, fully mobilize the enthusiasm and creativity of faculty and staff, and promote various in-depth reforms within colleges and universities. New models such as parallel management, transposition management, and incentive-driven management based on management objects have become an important way for traditional human resource management to transform to modern management. At the same time, managers are required to strengthen the construction of talent teams, optimize resource allocation, and strengthen job appointment assessment, etc., for construction. A healthy and harmonious human resource management environment in colleges and universities provides strong support.
\end{abstract}

\section{Subject Areas}

Human Resource Management

\section{Keywords}

Human Resources, Management Model, Colleges and Universities

\section{Introduction}

Human resource management in colleges and universities refers to the use of scientific principles and methods, to plan and organize various levels of personnel in the school, to guide, coordinate and control interpersonal and personnel relations, and to do a good job on the employment, recruitment, deployment, exchange, rewards and punishments, appointment and dismissal, training, assessment, wages and benefits, rank promotion, retirement of faculty and staff, 
according to the law of talent growth and the mission of the school, to achieve the goal of high efficiency and high benefit in the utilization of human resources in colleges and universities. Specifically, human resource management in colleges and universities refers to the management of the entire process of recruitment, hiring, training, promotion, transfer, and evaluation of employees in colleges and universities. The mutual coordination between faculty and staff, education, and social environment achieves the purpose of everyone doing what they can do, what they should do, and doing their best [1].

The implementation of human resource management in universities is determined by the special nature and strategic position of universities. Colleges and universities are places where talents gather and cultivate talents. Today, as the internal environment of colleges and universities has changed, traditional personnel management has severely hampered the survival and development of colleges and universities. Therefore, intensifying the development and management of human resources in colleges and universities is an inevitable choice for colleges and universities to win in the fierce competition, the purpose of this article is to explore the new models of human resource management with the hope of being beneficial to the management of human resources in colleges and universities.

\section{The Role of Human Resource Management}

\subsection{The Implementation of Human Resource Management is Conducive to Improving the Level of Competition in Colleges and Universities}

Teachers are the main body of colleges and universities and the core factor of the development of colleges and universities. The survival and development of colleges and universities directly depend on the overall quality of the teaching staff. Under the background of the internationalization and marketization of higher education in the new century, the competition for human resources is becoming more and fiercer. The implementation of human resource management in colleges and universities, strengthening the construction of the teaching staff, and establishing a sound talent training and distribution mechanism can continuously improve the quality and level of the teaching staff, and attract and retain talents [2].

Every job in colleges and universities must be completed by people. The coordination and development of various management tasks such as teaching, scientific research, and logistics services depend on the overall quality of these staff, the degree of coordination between people, and the personnel, and the suitability of the job. Therefore, the management of colleges and universities is established on the basis of human resource management.

\subsection{The Implementation of Human Resource Management Can Fully Mobilize the Enthusiasm and Creativity of Faculty and Staff}

Scientific supporting measures, strict and thorough assessment, open talent 
concept, fair and fair employment system, etc., can fully mobilize the enthusiasm and creativity of faculty and staff [3]. The rational use and development of human resources is the key to improving the education and teaching quality and school-running efficiency of colleges and universities in the $21^{\text {st }}$ century.

\subsection{The Implementation of Human Resource Management is the Need to do a Good Job in Various Tasks}

Each faculty member has a job position. Through human resource management, the personnel engaged in various tasks are organically divided into various categories, so that they are interconnected and dependent on each other, forming a division of labor, cooperation, and benign interactive relationship. Good administrative management and logistics services can promote the development of teaching and scientific research, and put forward higher requirements for administrative management and logistics services, and promote administrative management services to a new level [4].

\subsection{The Implementation of Human Resource Management Can Promote Various Deep-Level Reforms within Colleges and Universities}

The school's development goals, school positioning, management model, discipline construction and other major decisions need to be strengthened in human resource planning, performance management, salary management and other management. Human resource management is not only the focus of college reform, but also the mobilization of colleges and universities [5]. The positive factors of the faculty and staff are also an important guarantee for the overall improvement of the school's efficiency, teaching quality and overall level.

\section{Present Human Resource Management Modes}

\subsection{Parallel Management Mode}

In the Internet + environment, most colleges and universities have quickly built up an information platform for human resource management with the help of computer technology. Compared with the traditional hierarchical management model, the platform pays more attention to the sharing of resources, the cooperation between management objects and managers, and business innovation and development. The relationship between the management objects and managers integrated into the platform is an equal community, without any difference between the center and the edge. This parallel management model not only improves the self-status of the management object, but also strengthens the manager's ability to centralize management, effectively promoting the harmonious development of human resource management.

\subsection{Transposition Management Mode}

The role of managers is not only pure management, but more importantly, they 
must have a management philosophy that is eager to know what they want and what employees need to worry about. This requires managers to think about problems from the perspective of management objects, and establish a waste management model based on integrity and communication as a bridge. Transposition management is an advanced and efficient management method, but it is not human relations management, let alone accommodating management, and cannot be mixed with personal feelings [6]. It is necessary to make full use of the advantages of transposition management to provide powerful emotional, support and communication channels for human resource management and sustainable development of universities, so that the majority of faculty members can gain mutual respect and trust, and fully enjoy transposition. Managers' transposition management brings happiness.

\subsection{Incentive-Driven Management Mode}

Incentive drive refers to a series of measures to improve the enthusiasm of the management object, and urge them to give full play to their own intelligence. Incentive drive is the core element that determines the work efficiency of the management object, and it is also a prerequisite for creating a stable and harmonious human resource management environment. A good incentive drive cannot rely on subjective assumptions. A person's performance and abilities must be fully referenced to everyone's opinions. Based on the principle of fairness and justice, a set of open, transparent, scientific and fair evaluation system must be established to maximize the mobilization of employees. Enthusiasm and subjective initiative, based on motivation and drive, to build a human resource management system in colleges and universities can effectively mobilize the enthusiasm and creativity of faculty and staff.

\section{Innovative Thinking on Human Resource Management}

\subsection{Strengthen Talent Team Planning}

At present, the competition of the comprehensive strength of various colleges and universities has been mainly manifested in the competition of having talents. Talent team planning is to do a good job of talent training and talent flow, and actively coordinate the relationship between the two to create a good environment for normal teaching and research work. This requires human resource managers in colleges and universities to take a long-term view to achieve the optimization of talent sources, the professionalization of talent training, to ensure that talent reserve is forward-looking, and talent evaluation is profitable.

\subsection{Optimize the Allocation of Human Resources}

Efficient human resources are mainly composed of teaching personnel, scientific research personnel and management personnel. The allocation of human resources refers to the rational allocation of these resources through various methods, and to make the best use of their talents to bring maximum benefits for 
the development of the school. Human resource managers should follow relevant theories and methods, try their best to match positions with reasonable proportions, and make the best use of their talents. This will not only help reduce internal friction, but also maximize the role of talents [7].

\subsection{Strengthen Job Competition and Assessment}

There are three types of posts in colleges and universities: professional and technical posts, management posts, and labor and attendance posts, each of which coexists in its independent form. Among them, job competition is one of the effective means to ensure reasonable appointments among various and all levels of positions [8]. Colleges and universities can formulate corresponding mechanisms according to their own actual conditions and implement step-by-step competitive recruitment to ensure that personnel with outstanding work performance and who meet the basic qualifications of higher-level positions are selected. At the same time, strengthen the assessment of the appointment period to provide a strong guarantee for the smooth completion of the basic duties and tasks of the appointment position.

\section{Conclusion}

In the Internet+ era, human resource management in universities has achieved healthy development. The problems of traditional human resource management have seriously affected its development speed, and new thinking about its management model and innovative management has to be produced. New models such as parallel management, transposition management, and incentive-driven management based on management objects have become an important method of traditional human resource management transformation and modern management. At the same time, managers need to strengthen the construction of talent teams, optimize resource allocation, and strengthen job appointment assessment. A healthy and harmonious human resource management environment in colleges and universities provides strong support.

\section{Conflicts of Interest}

The author declares no conflicts of interest.

\section{References}

[1] Abdurexitia, A. (2011) Research on the Development and Management of Human Resources in Colleges and Universities. Journal of Hubei Correspondence University, No. 1, 12-13.

[2] Wang, B. (2013) research on Performance Management of Higher Vocational Colleges Based on Stakeholder Theory. Adult education in China, No. 2, 19-21.

[3] Wang, Y.G. (2012) Research on Performance Management of University Managers Based on Peripheral Performance Theory. Jiangsu Higher Education, No. 5, 118-119.

[4] Ren, Z.P. (2004) Development and Management of Human Resources in Colleges 
and Universities. Journal of Henan Normal University Philosophy and Social Science Edition, No. 31, 165-166.

[5] Chen, X.F. (2009) Research on the Problems and Countermeasures of Human Resource Management in Chinese Universities. Journal of Guangxi Economic Management Cadre College, No. 1, 106-107.

[6] Li, L. and Wu, Z.P. (2015) On the Construction of the Teaching Staff Management Mode of Open Private Colleges and Universities. Cultural and Educational Materials, No. 11, 85-86.

[7] Zhou, J.J. (2010) Management Mechanism of Colleges and Universities in China Based on Western Incentive Theory. Research on Incentive Mechanism. Guangxi Education Vocational and Higher Education Edition, No.7, 61-63.

[8] Xiao, J. (2018) A Preliminary Study on the New Generation Employees' Human Resource Management and Enterprise Sustained Competitive Advantage: From the Perspective of Resource-Based View. American Journal of Industrial and Business Management, 8, 2364-2374. https://doi.org/10.4236/ajibm.2018.812158 